\title{
DEVELOPING GLOBAL LEADERS THROUGH DOCTORAL EDUCATION ${ }^{1}$
}

Ginette Lemire Rodger ${ }^{2}$

Rodger GL. Developing global leaders through doctoral education. Rev Latino-am Enfermagem 2004 setembro-outubro; 12(5):816-20.

Nursing leadership has become a major theme of discussions in many countries. The phenomenon is also present in nursing as the profession is redesigning and reinventing itself in all domains of practice. This paper discusses the development of global nursing leaders through doctoral education in the context of $21^{\text {st }}$ century realities. Next, two meanings of global leadership of nursing are reviewed. Finally, doctoral education is focused by looking at worldviews and the challenges ahead in preparing global nursing leaders for the $21^{\text {st }}$ century.

DESCRIPTORS: nursing; leadership; education, higher

\section{EL DESARROLLO DE LIDERAZGOS GLOBALES MEDIANTE LA EDUCACIÓN DE DOCTORADO}

El liderazgo en enfermería se ha vuelto un importante tema de discusión en muchos países. El fenómeno también está presente en la enfermería, ya que la profesión está redibujándose y reinventándose en todas las áreas de la práctica. Este artículo discute el desarrollo de liderazgos globales en enfermería mediante la educación de doctorado en el contexto de las realidades del siglo $21^{\circ}$. Enseguida son revisados dos significados del liderazgo global en enfermería. Finalmente se destaca la educación de doctorado al analizar las perspectivas del mondo y los desafíos que debemos afrontar en la preparación de liderazgos en enfermería para el siglo $21^{\circ}$.

DESCRIPTORES: enfermería; liderazgo; educación superior

\section{O DESENVOLVIMENTO DE LIDERANÇAS GLOBAIS ATRAVÉS DA EDUCAÇÃO DE DOUTORADO}

A liderança em enfermagem tornou-se um importante tema de discussão em muitos países. $O$ fenômeno também se manifesta na enfermagem enquanto a profissão está se redesenhando e reinventando em todas as áreas da prática. Este artigo discute o desenvolvimento de lideranças globais em enfermagem através da educação de doutorado no contexto das realidades do século 21. A seguir, são revisados dois significados de liderança global em enfermagem. Finalmente, destaca-se a educação de doutorado ao analisar as perspectivas do mundo e os desafios a serem enfrentados na preparação de lideranças globais de enfermagem para o século 21.

DESCRIPTORES: enfermagem; liderança; educação, superior

\footnotetext{
${ }^{1}$ International Network for Doctoral Education in Nursing (INDEN) Conference Sheraton Centre - Toronto, Ontario, Canada - October 31, 2003; ${ }^{2}$ Chief of Nursing, The Ottawa Hospital, Ottawa University Heart Institute, The Rehabilitation Centre, Adjunct Professor, University of Ottawa and Adjunct Professor, Queens University, e-mail: glrodger@telusplanet.net
} 
INTRODUCTION

Thank you for inviting me to join you in participating in the International Network for Doctoral Education in Nursing (INDEN) conference. It is a pleasure to be with colleagues that have gathered to reflect on the theme of "Visionary leadership for doctoral education for the Twenty-first Century".

The theme of leadership has become a major theme of discussions in Canada and in many countries as the world is repositioning itself to meet the challenges of the era. The phenomenon is also present in nursing as the profession is redesigning and reinventing itself in all domains of practice, I mean the clinical, educational, managerial and research domains. At nursing conferences I have attended during the last two years, we could feel the transition. The tone of the discussions were very realistic taking into account the complexity of the issues and changing times but at the same time the tone was energizing as nurses were creating the transition. Today's Program is another fine example of this phenomenon. It reflects the evolution in our thinking about doctoral education and the presence of new health care challenges for the $21^{\text {st }}$ century.

To cover the topic of this panel on "Developing global leaders through doctoral education." I will first, review elements of the $21^{\text {st }}$ century realities that will affect the development of a new form of leadership. Second, I will review two meanings of global leadership of nursing. Third, I will focus on doctoral education looking at worldviews and the challenges ahead as we prepare global nursing leaders for the $21^{\text {st }}$ century.

\section{$21^{\text {ST }}$ CENTURY REALITIES}

In 1994, at the United Nations conference on the "World's Transformation: Conflict or Harmony?" Dr. Bezanson $^{(1)}$, Canadian Director General of the International Development Research Council concluded that the transformation we are living is so profound that no one can foresee either the journey or the outcomes. It seems that nations of the world, groups and individuals that are able to create and access knowledge and technology are having an increasing influence over the destiny of the world.

The multitudes of changes that are taking place create an unsettling reality that is part of the transition to a new era, the information age. Words such as cyberspace, genetic hardware and trade patterns are reflection of this new era. Words such as, chaos which now means randomness of systems constrained by a type of order that is non-linear ${ }^{(2)}$; words such as, system which means an assembly or combination of parts that form a complex unitary whole"(3) and words such as paradox which means beyond what is thought as conventional or commonly accepted or seems self-contradictory ${ }^{(3)}$, all these words are part and parcel of everyday life. Even new sciences are being conceptualized with the convergence of empirical evidence. One such example is the complexity science.

Complexity is "a description of the complex phenomena demonstrated in systems characterized by non-linear, interactive components, emergent phenomena, continuous and discontinuous change and unpredictable outcomes. Complexity is usually understood in contrast to simple, linear and equilibrium-based systems ${ }^{(4)}$.

What does all this have to do with global leaders in nursing...? A lot actually, because it has a direct effect on the type of leaders the new era demands. Since the era is grounded in knowledge, the leaders must be well prepared in their discipline.

About six month ago, four organizations convened a conference at the University of Minnesota where 150 scholars, scientists, educators, practitioners in diverse fields from cognitive psychology to computer sciences to genetic to critical care to business management to discuss the application of complexity science to healthcare and to think of new ways to care for patients and to lead in our organizations and in the whole health care system.

At that conference, Holland ${ }^{(5)}$ elaborated and described this new science as the science of the $21^{\text {st }}$ century, distinct from Newtonian reductionism that has guided scientific thinking for over three centuries.

He also elaborated on how "complexity science can guide our understanding of the health care system, a multi-layered system largely driven by rapidly changing technology and information. In healthcare organization and practitioner agents make up a continuously evolving system because of their innovative, diverse and progressive adaptations. Knowing the building blocks of the organizational system and its core processes is critical. Studying the interfaces of the building blocks allows system leaders to ask questions based on the flows or patterns among the processes, identify the feedback loops, explore 
the interfaces and ultimately identify an efficient system. With agents acting collectively, broken healthcare system interconnections can be identified and changed. Interactions among these agents encounter boundaries and boundaries in the healthcare system may be the "bottom line" that constrains interactions".

The realities of the $21^{\text {st }}$ century are already evident in our working environments in all domains of practice. The organization of work of the Third Wave ${ }^{(6)}$ with its complexity and chaos is visible. The nature of the organization of work is changing, units of operation are quasi-autonomous with some evidence of integration to the whole, there are very few control points, little standardization, flexibility and movement which are part of networks ${ }^{(7-9)}$. This new reality has major implications for the form of leadership needed.

\section{NEW FORM OF LEADERSHIP}

Before I comment on the form of leadership for the $21^{\text {st }}$ century, let me first, define what I mean by leadership. Leadership is the process of influencing activities and persuading a group in its effort toward goal setting and goal achievement ${ }^{(10-11)}$.

Bryman $^{(12)}$ reviewed the scholarly work among social scientists and psychologists and concluded that the field of study lacks an agreed upon framework and that the research and theory have been trivial and contradictory and therefore the concept is difficult to define. The analysis of the research on this topic revealed four stages of development: 1. the trait approach in the 1940s, which seeks to determine the personal characteristics of leaders. The assumption is that leaders are born not made; 2. the style approach between 1940 and 1960 which focused on the behaviour of the leader - since behaviour can be changed then the emphasis was on training; 3 . the contingency approach between the 1960 and 1980 which focused on situational factors that are central to understanding the phenomenon of leadership and the variables that can moderate the effectiveness of different leadership approaches; and finally, from the 1980s to today, the new leadership approach which focuses on a number of approaches but seems to signal a new way of conceptualising and researching leadership such as, transformational, visionary, charismatic or simply, leadership. These new leadership approaches are a response to a changing world.

\section{GLOBAL LEADERS}

Allen ${ }^{(13)}$ reflects on the leadership development needed in these terms, "the effective nurse leader must be able to navigate successfully in the current turbulent healthcare environment...the growth of the global economy, ever evolving healthcare and communication technology, the rise of the informed healthcare consumer... are just some of the factors that are changing the way in which healthcare organizations conduct business...these unique attributes of the healthcare industry make the work of nursing leadership challenging and complex, requiring diverse expertise and knowledge, superb critical-thinking skills and exceptional interpersonal capabilities".

\section{Globalization}

Global leaders in the literature are related to increased globalization created by the movement across borders of information, material and people. Major worldwide trends point to increased global interdependency and interrelatedness to a growing need to overcome barriers that separate cultures, and to the development of new leadership that is culturally fluent and aware of crosscultural opportunities and problems ${ }^{(14)}$. Maznevski \& DiStefano ${ }^{(15)}$ describes global leaders in these terms, "global leaders must develop a strong portfolio of technical, interpersonal and conceptual skills appropriate for managing the most complex of all possible situations". In their work on the development of global leaders they identified that developing global team is an effective way to facilitate development of global leaders. The development of in-depth knowledge of their own area of specialty is key but must be coupled with knowledge of other related areas and an understanding of the whole system in which it is operating. The development of strong skills should be in three areas: learning and adapting, managing relationship and managing ambiguity.

We have benefited from wonderful global leaders in nursing and the International Council of Nurses (ICN) has facilitated the process of leadership development since the mid 1980s. ICN has played a leadership role in the areas such as credentialing and health human resources planning As well, in some countries, investments were made in preparing nurses for global leadership. I benefited from such a program as Executive Director of the Canadian 
Nurses Association when the Canadian International Development Agency (CIDA) provided an orientation to the health care reality of each continent of the world to facilitate the development of partnerships in health and nursing.

All domains

Global leaders in nursing can also have another meaning in line with the new era. It may mean to ensure leaders in all domains of practice and leadership that transcend all domains. One of the great challenges the nursing profession is facing is the development of leaders in all domains but in particular, the clinical domain. Nursing managers, educators and researchers have been expected to exercise their leadership. Most of the infrastructures in health care have facilitated this exercise. This is not the case for clinical nurses. In order to create an environment that is conducive to clinical leadership the infrastructures must be changed including the locus of control for decisions regarding clinical questions and nurses must be prepared to be leading the policy decisions around clinical practice. In a large academic health science center like The Ottawa Hospital with 3600 nurses, we have estimated the at least 500 nurses are required to exercise their leadership on an ongoing basis.

When we consider the characteristics of the organization of work of the $21^{\text {st }}$ century with quasiautonomous units of operation we need nursing leadership to be present in each of these units.

\section{DOCTORAL EDUCATION}

$D^{\prime} C r u z{ }^{(16)}$ characterizes graduate programs in these terms and I quote, "graduate education in most university departments is firmly grounded in the academic research paradigm. Much of the focus is on preparing candidates for a lifetime of scholarly research. Using an apprenticeship model that has been largely unchanged since medieval times, graduate schools prepare their students for the rigours of the peer review process upon which publication, tenure and promotion depend so heavily".

For some ${ }^{(17)}$ doctorally prepared nurses are acutely needed in the discipline to further develop and expand the science, as well as to prepare its future educators, scholars, leaders and policy makers".
For the American Association of Colleges of Nursing ${ }^{(18)}$ the purpose of the doctoral degree is to prepare nurses for a lifetime of intellectual enquiry, creative scholarship and research. Graduates are prepared to be leaders in government, business, and industry, as well as academia; and this preparation results in an extension of knowledge".

In order to meet the challenge of preparing global leaders, not only for education and research but in all domains of practice and at all levels (from local to international) we need a revision of nursing scholarship. Noted educator Ernest Boyer ${ }^{(19)}$ proposed a new paradigm for defining scholarship in the now classic, "Scholarship Reconsidered." Rather than being solely concerned with the discovery of new knowledge, Boyer posited three other aspects to scholarship: dissemination, integration and application.

Nurse scholars have also stated their opinions about the meaning of scholar and scholarship. Meleis ${ }^{(20)}$ for example, wrote that, "a scholar is a person who has a high intellectual ability, is and independent thinker and an independent actor, has ideas that stand apart from others, is persistent in the quest for developing knowledge, is systematic, has unconditional integrity, has intellectual honesty, respects all divergent opinions and. Of course, is a person who is deeply engaged in the development of knowledge in the field".

Scholarship, traditionally viewed as part of or generated in a university setting, must be an expectation in all settings in which a community of scholars from both discipline and practice can and do coexist.

\section{CHALLENGES}

Developing global leaders through doctoral education will challenge the commonly held view that doctoral programs exist specifically to prepare educators and researchers. The larger notion of scholarship will have to prevail. The preparation of the global leaders needed for the $21^{\text {st }}$ century will also challenge the development of programs that will meet the challenge of globalization and the new forms of leadership for professional practice.

For doctoral education, some of the challenges will include:

- reconceptualization of doctoral education to prepare 
leaders at all levels from the international to the locallevel and for all domains including clinical and managerial in spite of the structures and barriers.

- development of partnerships at all levels, from the international to the locallevel!

- intentional development of joint academic and clinical infrastructures that are multi- sites and multi-national to leverage funds, policy, resources, etc.

- promotion of a culture of research with in all policies, protocol, projects etc.... evidence-based and best practice. - innovation/innovation/ innovation.... we should not hear

\section{REFERENCES}

1. Bezanson KA. From Megatrends to sustainability: The challenge for international development organizations. UNPD Roundtable on Global Change: Social conflict or harmony? Ottawa (ON): International Development Research Council; 1994.

2. Hamilton P, West B, Cherri M, Mackey J, Fisher P. Preliminary evidence of non-linear dynamics in births to adolescents in Texas, 1964 to 1990 . Theoretic and Applied Chaos in Nursing 1994; 1(1):15-22.

3. Webster's encyclopaedia unabridged dictionary of the English language. New York: Portland House; 1989.

4. Zimmerman B, Lindberg C, Plsek P. Edgeware: Insights from complexity science for health care leaders. Irving (TX): VHA Inc; 1998.

5. Holland J.Applying complexity science to health and healthcare. Minneapolis (MN): Center for the Study of Health care Management, University of Minnesota; 2003.

6. Toffler A.The third wave. New York: William Morrow; 1980.

7. Toffler A,Toffler H. Getting set for the coming millennium. Futurist 1995 March-April:13-4.

8. Drucker PF. Foreword: Not enough generals were killed. In: Hesselbein F, Goldsmith M, Beckhard R, editors. The leader of the future: New visions, strategies, and practices for the next era. San Francisco (CA): Jossey-Bass; 1996. p. xi-xv 9. Mintzberg $\mathrm{H}$. No formulas or management model allowed. Forum 1997; 10:8-9.

10. Stogdill RM.Leadership, membership and organization. Psychol Bull 1950; 47:1-14.

11. Bass BM, Stogdill RM. Bass and Stogdill's handbook of leadersip: Theory, research, and managerial applications. $3^{\text {rd }}$ ed. New York (USA): Free Press; 1990.

12. Bryman A. Leadership in organizations. In: Clegg SR, Hardy C, Nord WR, editors. Handbook of organizational studies.. Newbury Park (CA): Sage Publications; 1996. p. 276-92.

13. Allen DW. How nurses become leaders: Perceptions and beliefs about leadership development. J Nurs Admin 1998; 28(9):15-20.

14. Smith RC, Lischin S. Intercultural relations and the development of global leadership. Highland (NJ): Project for intercultural development; 1987.

15. Maznevski ML, DiStefano JJ. Global leaders are team players: developing global leaders through membership on global teams. Hum Resour Manage 2000; 39(2/3):195-208. from this community "it has never been done before".

For clinical practice the challenges will include:

- reorganization of the work place to value all forms of leadership.

- development of leadership in all domains of practice in an interdependent fashion.

- reconceptualization of the notion of leadership not essentially equated to management positions.

- preparation of a generation of nurses who are able to exercise their leadership knowledge and skills at the local, provincial, national and international levels.

16. D'Cruz JR. Is graduate education model inappropriate for leadership developments? Health Papers 2003; 4(1):69-74. 17. Chambers KB. ABCs of Doctoral Education: The Doctoral Student Alphabet. Graduate Res Nurs [serial online] 2001 June [cited 2004 May 4]. 3(1) [6 screens]. Avaliable from: URL: http:/ /www.graduateresearch.com/chambers.htm

18. Carty R, O'Grady E, Orn-Anong W, Bull J. Opportunities in Preparing Global Leaders in Nursing. J Prof Nurs 2002; 18(2):70-7.

19. Boyer EL. Scholarship reconsidered. Lawrenceville (NJ): Princeton University Press; 1990.

20. Meleis AF. Theoretical nursing: Development and progress. $2^{\text {nd }}$. ed.Philadelphia (NJ): Lippincott; 1991. 